\title{
Non-State Actors in the Russo-Ukrainian War
}

\author{
Joshua P. Mulford
}

US Army, http://www.army.mil/

\begin{abstract}
The current war in Ukraine has highlighted the fact that in this new age of warfare non-state actors play a larger role than ever before. The influence of the media, think tanks and academia, religious groups, organized crime, war militias, NGOs and GONGOs, and the Ukrainian diaspora is pervasive. Kremlin-controlled media coverage of the war in Eastern Ukraine, including the downing of the $\mathrm{MH}-17$ jet, is offset by the newer grassroots pro-Ukrainian media outlets such as Ukraine Today. Think tanks and academia focused on Ukraine and Russia are also battling for visibility in the government and among the populous.

The impact of religious groups on the Ukrainian conflict is best featured in the Russian Orthodox Church's rationalizing the invasion of Crimea as Russia's divine right. The Ukrainian church, a subset of the ROC, has broken off and played a proactive role in assisting the war effort by pro-Ukrainian militias. The almost concurrent rise of militias and organized crime in Ukraine pose as a precarious issue for the future of the country. As the government is incapable of regaining sovereignty of its territory, stand-alone militias have risen to fight the Russian invasion in Eastern Ukraine. Organized crime has capitalized on the instability of the region, and with the annexation of Crimea, a new system of black market activities has been opened. The outside world is taking an interest in the Ukrainian plight, as well as in the form of NGO support, and in the case of Russia, GONGOs to promote policies in line with their agendas. The Ukrainian diaspora has also fought to influence policy making towards Ukraine, forming committees and sending supplies to the front line.

It is unclear how much influence these non-state actors will have in the future of Ukraine, but it is quite certain that they each play a significant role in the way the conflict is perceived.
\end{abstract}

Keywords: Non-state actors, Ukraine, Crimea, Russo-Ukrainian war. 


\section{Introduction}

Non-state actors have played a significant role in creating and influencing the current war in Ukraine. From competing narratives broadcasted by media outlets to misinformation campaigns designed to confuse and cause fear, the media strive to gain the advantage of discourse. Likewise, think tanks and academia influence not only public discourse, but political agendas and, ultimately, policy. Religious groups also take sides either by supporting Ukrainian citizens adversely affected by the conflict or actively participating in promoting a nationalistic narrative with religious and historical themes. ${ }^{1}$ The Russo-Ukrainian War and illegal occupation of Crimea have created opportunities for organized crime to flourish in the vacuum left by the Ukrainian government's inability to control its sovereign territory. On both sides of the war militias have quickly organized and are often more effective than government forces. Non-governmental and government organized non-governmental organizations (NGOs and GONGOs) play a variety of roles within Ukraine, while also bearing transnational influence. The Ukrainian diaspora continues to provide varied levels of support for their native country. The extent to which non-state actors will have an impact on the outcome of the conflict is yet to be determined; however, non-state actors have and will continue to play a significant role from the battlefields of eastern Ukraine to the halls of the US Congress.

\section{Media}

Russian mass media is controlled by the Kremlin. This is a characteristic of autocratic states that fear counter-narratives to the government's approved messaging. As President Vladimir Putin observed the waves of social unrest over the last decade, from color revolutions to the Arab Spring, he became aware of the power of social media and messaging in the new domain of war - information space. Russia Today (RT) and Channel One are two of the largest stateowned television networks that broadcast pro-Russian multilingual programming worldwide. Russia has transformed a traditional non-state actor into an instrument of the state to shape domestic and foreign opinion and silence the opposition.

The use of media to demoralize, confuse and delay opponents was most notably seen after the downing of flight MH17. Western media networks asserted, based on initial evidence, that Russian troops or Russian-backed separatists were responsible. Russian mass media quickly put into question initial claims by accusing Ukrainian troops or NATO forces of the act. This use of disinformation created conspiracy theories that diminished the truth. ${ }^{2}$

1 Mykhailo Cherenkov, “Orthodox Terrorism," First Things, May 2015, available at www.firstthings.com/article/2015/05/orthodox-terrorism (accessed 20 March 2016).

2 John Lough, et al., Russian Influence Abroad: Non-state Actors and Propaganda (London: Chatham House, 2014), 8-9, available at http://www.chathamhouse.org/sites/ 
RT was established in 2005 to familiarize the world with the Russian viewpoint. In 2015, the network enjoyed a budget of $\$ 275$ million provided by the Russian government. Notwithstanding its massive budget, RT has not been as effective as Russia had hoped, and is now considered a laughable source of information. ${ }^{3}$ In fact, in March 2014 news anchor Liz Whal resigned on air in opposition to the "whitewashing" of events by the Russian government, stating that it was against her morals and ethics as a journalist to continue working at $\mathrm{RT}^{4}{ }^{4}$ The network continues to provide extensive coverage of the situation in Ukraine and greatly influences opinions of Russians and Ukrainians, especially in Crimea and eastern Ukraine, where Russia censors any pro-Western media.

Ukraine, along with the West, is struggling to find an appropriate response to Russia's advantage in the information space. However, despite spending billions of dollars on propaganda campaigns, Russian media are losing credibility, and the international community has a lower perception of Russia than before Ukraine's Revolution of Dignity. Unified Western action in Ukraine has been slow much to the delight of Russian authorities, but any good will toward Russia that existed prior to 2013 has been lost. A Pew research poll conducted in April and May 2015 found that of the eight NATO counties surveyed, only 26 percent of respondents had a favorable opinion of Russia. ${ }^{5}$ The misunderstanding of the information space by the Russian state-sponsored media has shown the importance of free media's role as a non-state actor in building trust and a believable dialogue with the international community. ${ }^{6}$

The late Boris Nemtsov's daughter, Zhanna Nemtsova, has claimed Russian propaganda killed her father, saying, "It kills reason and common sense but it also kills human beings." Nemtsov had been preparing a report that would challenge Putin's claim that there were no Russian troops in Ukraine. However, he was gunned down outside the Kremlin on 27 February 2015, days before he was supposed to lead an anti-war rally against Russia's actions in Ukraine. For years, Russian media demonized opposition figures like Nemtsov as "national traitors," known in Russia as the "fifth column." In some instances, propaganda may be severe enough to incite people to commit unthinkable acts of violence,

files/chathamhouse/field/field_document/20141024RussianInfluenceAbroad.pdf (accessed 18 July 2015).

3 Ivan Nechepurenko, "Russia Only Has Itself to Blame for Lost Influence in Post-Soviet Sphere," The Moscow Times, 30 June 2015, http://www.themoscowtimes.com/ news/article/russia-only-has-itself-to-blame-for-lost-influence-in-post-soviet-sphere/ 524757.html (accessed 1 July 2015).

4 Liz Whal, "RT Anchor Quits on Air," YouTube video, 5 March 2014, https://www.youtube.com/watch?v=55izx6rbCqg (accessed 3 July 2015).

5 Nechepurenko, "Russia Only Has Itself to Blame."

6 Mark Galeotti, "The West Is Too Paranoid about Russia's 'Infowar," The Moscow Times, op-ed, 30 June 2015, www.themoscowtimes.com/opinion/article/the-west-istoo-paranoid-about-russias-infowar-op-ed/524756.html (accessed 1 July 2015). 
as was the case in Nazi Germany, Rwanda and now in Ukraine. ${ }^{7}$ Nemtsov's murder was significant as he was a major opposition figure outspoken in his condemnation of the Russian annexation of Crimea and support for separatists in eastern Ukraine.

Meanwhile, the Ukraine Today network was founded in August 2014 as a Kyiv-based English news outlet with the goal of strengthening "international communications, understanding, and peace." ${ }^{8}$ At the Black Sea Security Conference in Bucharest, Strategic Communications Director Lada Roslycky appealed to the participants to stop calling what is going on in Ukraine as a crisis or conflict and call it what it is - a war. ${ }^{9}$ News outlets such as Ukraine Today and KyivPost provide media coverage to influence international perception of the situation in Ukraine. ${ }^{10}$ Both provide a wide range of platforms to present a different perspective to the Russian narrative.

There are grassroots efforts to combat Russian propaganda within Ukrainian civil society. StopFake.org is an online community created by alumni and students from the Mohyla School of Journalism in Kyiv. This group of independent journalists is determined to protect the integrity and honesty of information that is found in the media about Ukraine. As of April 2015, journalists at StopFake.org had verified over 1,000 pieces of media and identified 400 pieces of false reporting. ${ }^{11}$ StopFake.org's work remains incredibly important by keeping Russian media in check and providing readers with an accurate story.

Founded in 1949 as an anti-Communist news network, Radio Free Europe / Radio Liberty (RFE/RL) initially received funds from the CIA. Currently, it receives funding from the Board of International Broadcasters (BIB), which is backed by the U.S. Congress. Despite the funding source, the BIB acts as a buffer between government and program content. The goal of the network is to spread information where open media is not allowed - mostly in autocratic, closed societies. ${ }^{12}$ RFE/RL has delivered significant reporting on the war, primarily seeking to influence Russian speakers in Ukraine.

The role of media in Ukraine has proven to shape what people know and influence how they act. Evidently, the restriction by Russian and pro-Russian authorities in Crimea and eastern Ukraine of various media outlets also plays into shaping the knowledge of society. Despite all of Russia's best attempts to promote one common pro-Russian story, independent and grassroots efforts are

7 Zhanna Nemtsova, "My father was killed by Russian propaganda, says Nemtsov's daughter," The Guardian, 19 June 2015, http://www.theguardian.com/world/2015/ jun/19/russia-boris-nemtsov-zhanna-nemtsova (accessed 30 June 2015). Ukraine Today, http://uatoday.tv/about (accessed 30 June 2015).

9 In honor of the realities on the ground and in respect for Ms. Roslycky's appeal in the paper the author prefers to label the current conflict in eastern Ukraine, the RussoUkrainian War.

10 Lada Roslycky, “Black Sea Security Program," 26 May 2015, Bucharest, Romania.

11 http://www.stopfake.org/en/about-us/.

12 Radio Free Europe / Radio Liberty, http://www.rferl.org/info/about/176.html. 
gaining momentum and leaving their own impact on the coverage and narrative of the conflict.

\section{Think Tanks and Academia}

Ukrainian and international think tanks are having a profound impact on domestic government reforms and are externally shaping the dialogue on how the international community should support the government in Kyiv and react to Russian aggression. Since the fall of the Soviet Union, think tanks in Ukraine such as the Ukrainian Centre for Economic and Political Studies (The Razumkov Centre), The Atlantic Council of Ukraine and The Europe XXI Foundation have enjoyed considerable political independence. The Institute for Economic Research and Policy Consulting (IER) is particularly well-known independent Ukrainian think tank. Reports developed by the IER include the effects of abolishing visa requirements for travel through the EU for Ukrainians, investment forecasts by region and the impact of the Deep and Comprehensive Free Trade Agreement (DCFTA) on various levels of Ukrainian society. ${ }^{13}$ The IER's role of providing in-depth analysis to policymakers and potential investors alike during a time of war should be highlighted. Its reports have a direct impact on the decisions of leaders, which have grave and long-lasting consequences for the viability of Ukraine.

A product of the Revolution of Dignity was the creation of the non-partisan NGO, Maidan of Foreign Affairs (MFA). Diplomats and experts who openly opposed Viktor Yanukovych government created MFA to discuss policy based on democratic ideals. MFA's main objectives are to provide expert opinion on foreign policy and national security, educate the public on key issues and promote greater policy debate. MFA has produced intelligence manuals for the army that are being used on the battlefields in eastern Ukraine as well as for formulating a strategy to regain Crimea. ${ }^{14}$

Russian think tanks and academia have increasingly become less independent as the government seeks to control them. Over time, their conclusions and instructions have become more aligned with the goals and narratives of the Kremlin. Individuals who fail to operate within the approved narrative face intimidation, and often choose to flee Russia. Former Provost of the New Economic School in Moscow, Sergei Guriev, now teaches in Paris after he was notified his lessons were not appreciated by the Kremlin. In 2015, the Russian parliament passed a law on "undesirable" organizations that threatened the security and order of Russia. Organizations that have been investigated as "undesirable" include Amnesty International, the Carnegie Foundation and Human Rights Watch. The new legislation has created a threatening environment for top Russian economists and experts leading to a brain drain, weakening the in-

13 The Institute for Economic and Policy Consulting, www.ier.com.ua/en/projects/.

14 The Maidan of Foreign Affairs, http://mfaua.org/about/?lang=en (accessed 1 July 2015). 
ternal dialogue inside Russia. ${ }^{15}$ This lack of domestic debate has led to a selfperpetuating relationship between government, think tanks and academia.

The most influential Russian think tank is the Russian Institute for Strategic Research (RISI) that openly supported the 2014 invasion of Ukraine. RISI has former ties to Russia's Foreign Intelligence Services (SVR) and thus remains a trusted source of expertise to the Kremlin. Additionally, RISI believes that the Russian Federation is the center of gravity in the former Soviet space, a counter-narrative to the international order led by the US, which believes all countries have the right to self-determination and sovereignty regardless of their size. ${ }^{16}$ The Russian narrative, called the "Russian World," in which Putin and the Russian Federation act as the sole security guarantor of Russian speakers everywhere, has played out in Ukraine as Putin maneuvers to ensure Ukraine looks east before looking west. As Russian think tanks continue to be investigated and labeled "undesirable," it is important to take heed of the consequential role that groups like RISI play and their effect on influencing policy toward Ukraine. $^{17}$

Think tanks outside Ukraine and Russia, such as the Washington-based Atlantic Council, Brookings Institute and Potomac Foundation strive to keep the attention of lawmakers on the dire situation in Ukraine with comprehensive expert coverage. These practitioners, professors and specialists lead panels at congressional hearings and develop thought-provoking reports that ignite policy discussion in the media and on Capitol Hill. For example, the Atlantic Council, Brookings and The Chicago Council on Global Affairs collaborated to produce a report titled Preserving Ukraine's Independence, Resisting Russian Aggression: What the United States and NATO Must Do. ${ }^{18}$ The report carried significant weight due to the high level of experience and expertise that was leveraged to produce and support it, and ultimately calls for greater US support for Ukraine in the form of lethal aid.

15 Andrei Kolesnikov, "Russia's Brain Drain: Why Economists Are Leaving," Carnegie Moscow Center, 26 May 2015, http://carnegie.ru/publications/?fa=60221 (accessed 1 July 2015).

16

Barack Obama, "Full Transcript: President Obama Gives Speech Addressing Europe, Russia on March 26," The Washington Post, 26 March 2014, https://www.washingtonpost.com/world/transcript-president-obama-gives-speechaddressing-europe-russia-on-march-26/2014/03/26/07ae80ae-b503-11e3-b89920667de76985_story.html (accessed 19 July 2015).

17 Paul Goble, "Russian Think Tank That Pushed for Invasion of Ukraine Wants Moscow to Overthrow Lukashenka," Eurasia Daily Monitor, 27 January 2015, www.jamestown.org/programs/edm/single/?tx_ttnews\%5Btt_news\%5D=43458 (accessed 1 July 2015).

18 Ivo Daalder, et al., Preserving Ukraine's Independence, Resisting Russian Aggression: What the United States and NATO Must Do (Washington, DC: The Atlantic Council, 2015), http://www.atlanticcouncil.org/images/files/UkraineReport_February2015.pdf (accessed 30 June 2015). 
The Atlantic Council's follow-up report, called Hiding in Plain Sight, documents evidence of Russian involvement in the ongoing war in Ukraine and was published in May 2015, the same month as the better-known Nemtsov report, appropriately titled Putin War. ${ }^{19}$ Both provide motives for Russian aggression, how Russia has executed the war and evidence based on photography, tapped phone conversations, interviews and social media. These reports have had minimal impact inside Russia, as Russian citizens care little about Russia's involvement in Ukraine and the government is unlikely to acknowledge military operations in response to the evidence provided by the late Nemtsov. ${ }^{20}$ Conversely, the reports have had a significant effect on policymakers on Capitol Hill, routinely referenced as lawmakers continue to put pressure on the Obama administration to provide lethal aid to the Ukrainian armed forces.

The Potomac Foundation provided break-through reporting and analysis on Russia's hybrid war in Ukraine in March 2015. The report was based on President Phillip A. Karber's personal experience on the front lines of the war in the Donbas region. The Ukrainian government requested an assessment of the current military situation in the East from the Potomac Foundation. ${ }^{21}$ These reports provide evidence of Russian involvement in Ukraine despite Putin's continued assertion that there are no Russian operations in Ukraine and thus Russia is not in violation of the Minsk II ceasefire agreement. ${ }^{22}$

Academia has also played a vital role in shaping the conversation and deepening the understanding of the causes and solutions to the war. Since the Revolution of Dignity began in late 2013, Washington D.C.-based universities have extensively provided students and the public with scholarly panels and publications from the West's misunderstanding of color revolutions to covering Ukraine's other war, rife with graft and corruption. In March 2015, George Washington University (GWU) hosted Ukrainian musician and EuroMaidan activist Sergei Fomenko. Fomenko and his band "Mandry" played several traditional Ukrainian folk songs at the opening of their exhibit titled "Ukraine. Road to Freedom," which brought the reality of the extreme measures Ukrainians took to change the status quo and avoid a dystopian future for their country to the students and public of Washington D.C. Forums and panels such as these continue to shine light on the war in Ukraine, which vacillates in and out of

19 Ilya lashin and Olga Shorina, Putin. War. An Independent Expert Report (Moscow, 2015), http://4freerussia.org/putin.war/Putin.War-Eng.pdf (accessed 30 June 2015).

20 Pavel Felgenhauer, "Nemtsov Report on Russian War in Ukraine Fails to Have Much Impact in Moscow," Fortuna's Corner, 14 May 2015, http://fortunascorner.com/ 2015/05/14/nemtsov-report-on-russian-war-in-ukraine-fails-to-have-much-impactin-moscow/ (accessed 30 June).

21 Phillip A. Karber, "Russia's Hybrid War Campaign," presentation the CSIS Russian and Eurasia Program, 10 March 2015, available at http://csis.org/event/russiashybrid-war-campaign-implications-ukraine-and-beyond (accessed 11 March 2015).

22 Pamela Engel, "Putin: I will say this clearly: There are no Russian troops in Ukraine," Business Insider, 16 April 2015, http://www.businessinsider.com/putin-i-will-saythis-clearly-there-are-no-russian-troops-in-ukraine-2015-4 (accessed 30 June 2015). 
public attention given the amount of coverage devoted to other major issues such as ISIS, the refugee crisis, and a possible British exit from the EU.

Academia also has provided valuable research and analysis resources in order to achieve greater understanding of the hopes and aspirations of the Ukrainian people, who often get overlooked as geopolitical differences take precedence. The University of Maryland's Program for Public Consultation along with the Kyiv International Institute of Sociology conducted a survey of Ukrainians in all regions (except Crimea) in order to insert to the voice of Ukrainians into public knowledge and discourse. ${ }^{23}$ The importance of understanding their opinions cannot be overstated, as various commentators and experts offer solutions to the current impasse between the Donbas region and the rest of Ukraine. A long-term and viable solution will have to take into consideration the University of Maryland's and Kyiv International Institute of Sociology's report.

\section{Religious Groups}

Current tensions between the Moscow Patriarchate of the Russian Orthodox Church (ROC MP) and the Ukrainian Orthodox Church of the Kyivan Patriarchate began in 2009. The leader of the ROC MP, Patriarch Kirill, gave spiritual support to Putin's "Russian World" ideology. These religious tensions have created confusion on the ground as competing and radical views create an atmosphere of distrust and instability. ${ }^{24}$ The ROC MP has played a significant role in supporting the Kremlin's narrative by articulating Russia's historical and religious links to Kyiv and Crimea. ${ }^{25}$ According to Adrian Karatnycky of the Atlantic Council, religious leaders "are creating a deep crisis, precisely because the church was instrumentalized by these major political actors." ${ }^{26}$ The cultural, historical and religious project known as Novorossiya received strong support from the Russian Orthodox Church (ROC), as it was seen "as an existential issue for the entire Holy Russia." However, the more ROC MP continues to support Russian aggression in Ukraine, the more it isolates itself now and for the future. $^{27}$

Kirill appeals to international bodies for support of the plight of Russian Orthodox priests in eastern Ukraine, but at the same time promotes violence to-

23 Steven Kull, The Ukrainian People on the Current Crisis (University of Maryland and Kyiv International Institute of Sociology, 2015), http://www.public-consultation.org/ studies/Ukraine_0315.pdf (accessed 9 March 2015).

24 Hannah Gais, "Putin's War Has Come to the Pews," U.S. News, 4 March 2015, http://www.usnews.com/opinion/blogs/world-report/2015/03/04/ukraine-crisisthreatens-to-further-fracture-orthodox-faithful (accessed 1 July 2015).

25 Katya Kumkova, "Orthodox Church Leader Reflects on the Religious Dimension of the Ukrainian Crisis," Eurasianet, 23 January 2015, http://www.eurasianet.org/node/ 71756 (accessed 1 July 2015).

26 Gais, "Putin's War."

27 Lough, et al., Russian Influence Abroad, 6. 
ward non-Russian Orthodox religious leaders. The ROC MP's view is that the rest of the world is evil and Russia is the example of good. Russian citizens, soldiers and mercenaries have been heeding the ROC MP's de facto call to defend against the threats to the Holy Russian Empire, which is a major recruitment tactic. $^{28}$ The religious war created by the ROC MP and Kremlin stokes greater hatred and deepens the commitment by Russian fighters in Ukraine, ultimately perpetuating the rifts within society.

Any short-term gains the Kremlin is trying to make by stirring religious conflict in Ukraine with help from the ROC MP will have greater long-term ramifications for the ROC internationally. ${ }^{29}$ The ROC MP's actions and controversial statements of its leader are creating a schism between the Ukrainian Orthodox Church, which falls under the MP, and the Ukrainian Orthodox Church of Kyivan Patriarchate. Worshippers are increasingly associating the Ukrainian Orthodox Church MP with Kremlin policies. These political differences are playing out in the pews, as 30 formerly Moscow-aligned parishes have thrown their allegiance behind the Kyivan Patriarchate. Like Kirill, leaders in the Kyivan Patriarchate make nationalistic statements such as former spokesperson Archpriest Heorhiy, who said the Moscow Patriarchate was "the Church of the Soviet Union." ${ }^{30}$ The failure of leaders in the Orthodox Church to refrain from deep involvement in the current war is undermining the social fabric of Ukraine.

Meanwhile, non-Russian Orthodox faiths have lived in constant fear and persecution, including the Ukrainian Orthodox Churches. In June 2014, proRussian separatists kidnapped and murdered four Pentecostal Church leaders in eastern Ukraine. Multi-faith religious leaders from Ukraine recently met at a conference in London and called on the international religious community and NGOs to support reconciliation and peace in Ukraine. They also asked world leaders to address the humanitarian crisis of 1.2 million internally displaced persons in Ukraine. ${ }^{31}$ Further, a damning report on religious freedoms in Russia, occupied Crimea and eastern Ukraine by the United States Commission on International Religious Freedom (USCIRF) classifies Russia as a Tier II country for freedom of religion. ${ }^{32}$ Russian policies and actions have contributed to this ranking as well, as has a 4,000-strong Russian Orthodox Army (ROA) operating

28 Paul Goble, "Moscow Patriarchate's Backing of Russian Aggression Undermining Russian Orthodox Church Everywhere," The Interpreter, 25 August 2014, www.interpretermag.com/moscow-patriarchates-backing-of-russian-aggressionundermining-russian-orthodox-church-everywhere/ (accessed 30 June 2015).

Ibid.

30 Maksym Bugriy, "The War and the Orthodox Churches in Ukraine," Eurasia Daily Monitor, 18 February 2015, www.jamestown.org/programs/edm/single/?tx ttnews[tt_news] $=43548 \&$ cHash $=3 d c 1$ a85482a515406a43403429694d66 (accessed $\overline{1}$ July 2015).

31 Ibid.

32 Katrina Lantos Swett et al., Annual Report 2015 of the U.S. Commission on International Religious Freedom (Washington, D.C.: USCIRF, 2016), p. 5. 
in eastern Ukraine, which conducts destructive operations against non-Russian Orthodox religious institutions. ${ }^{33}$

The Ukrainian Orthodox Church played a proactive role in supporting protestors during EuroMaidan by providing church facilities for anti-government military groups. ${ }^{34}$ Patriarch Filaret, the leader of the Kyivan Patriarchate, supports soldiers going to war in eastern Ukraine. Early this year he was in Washington DC, lobbying for military assistance to support the Ukrainian armed forces in order to defend the Ukrainian nation. Once the war broke out, the Church provided religious support and donations of money, clothes, food and transportation. According to Filaret, the Church has also provided the military with night-vision goggles. ${ }^{35}$

As a non-state actor, the Orthodox Church has the potential to play a constructive role by bridging the schisms in society, but until now both sides have only decreased the possibility of reconciliation between Ukrainians. The Orthodox Church has thus become a symbol of nationalism to both sides. Until the leadership of the ROC MP and Ukrainian Orthodox Church of the Kyivan Patriarchate decide that delving into the affairs of government is detrimental to society, they will continue to perpetuate the current war.

\section{Organized Crime}

The idea of the separatist's breakaway region as "The People's Republics" of the Donbas has been years in the making. As Russia remains a mafia-like state, it benefits from having weaker, smaller countries in its periphery. Princeton historian Stephen Kotkin coined the term "Trashcanistan" to describe the pervasive nature of corruption in many of the post-Soviet countries. Through the "transition" from Communism to capitalism, many organized crime bosses became oligarchs overnight, and some rose to be powerful politicians, prime ministers and presidents. In Ukraine in particular there has been a continuous line of political leaders who rose to power through nefarious means at the cost of the development of society. ${ }^{36}$

The Donbas region was the most corrupt and ungovernable region by far for either Moscow or Kyiv. As the locals say, "every third man in the Donetsk region is in prison, has been in prison, or will be in prison." ${ }^{37}$ In this paradigm,

33 Timothy C. Morgan, "Violence, Persecution Spread in Eastern Ukraine," Christianity Today, 6 May 2015, www.christianitytoday.com/gleanings/2015/may/violencepersecution-spread-in-eastern-ukraine.html (accessed 1 July 2015).

Lough, et al., Russian Influence Abroad, 7.

35 Kumkova, "Orthodox Church Leader."

36 Mark Galeotti, "How the Invasion of Ukraine Is Shaking Up the Global Crime Scene," Vice News, 6 November 2014, www.vice.com/read/how-the-invasion-of-ukraine-isshaking-up-the-global-crime-scene-1106 (accessed 1 July 2015).

37 Piotr Kosicki and Oksana Nesterenko, "Eastern Ukraine Has Been a Mafia State for Years. Can Kiev Break the Cycle of Violence?" New Republic, 5 June 2014, 
society does not progress and future generations are robbed of a better life. Moreover, these same individuals have openly pledged support to Russia and the separatists while claiming the Kyiv government illegally overthrew a democratically-elected Yanukovych government. ${ }^{38}$

The annexation of Crimea has opened a whole new market for organized crime and black market activities. Just as Transnistria, the breakaway pro-Russian enclave in Moldova, has proved profitable for Russian gangsters, Crimea has much more potential. International law enforcement organizations note that the destabilization in Ukraine has sent ripples around the world in terms of organized crime. As in Russia, Ukrainian political elite and organized crime networks are intertwined and reliant on each other for mutual support. Russian organized criminal networks are looking to expand smuggling routes using the Crimean port of Sevastopol and the prime smuggling port, Odessa. They move contraband including stolen cars, drugs, weapons and women throughout the Black Sea region. ${ }^{39}$

In 2014, Transparency International ranked Ukraine 142 out of 177 countries in the Corruption Perception Index. While Russia and Ukraine are in a desperate war for control of the Donbas region, Ukrainian underworld networks are collaborating with Russian ones to grow business opportunities out of the current situation in Ukraine. Moscow does not even need to engage Ukraine in a war, but simply rob Ukrainian society through Russian-Ukrainian organized criminal networks and links to corrupt officials. Russia's most dominant organized criminal organization is the Solntsevo network with strong ties to the "Donetsk clan," from which former Yanukovych's power base, the Party of Regions, stemmed. These former underground thugs are now actively serving in separatist units or attacking Ukrainian supporters and spreading terror through acts of violence. ${ }^{40}$

The conflict has ended any cross-border law enforcement cooperation between Russia and Ukraine, and organized crime networks are heating up in the absence of effective law enforcement networks. The "black hole" that Ukraine offers organized criminal networks within a modern state with infrastructure and ports is immense and lucrative. Thus, one of Russia's most effective responses to sanctions could be the "criminalization" of Ukraine and making it into a true "Trashcanistan." ${ }^{41}$

As the war rages on, organized criminal networks flourish and profit from the plight of internally displaced persons, the demands of war and the brave soldiers who fight and die for what the "Heavenly Hundred" in EuroMaidan

http://www.newrepublic.com/article/118010/eastern-ukraine-mafia-state-can-kievimpose-rule-law (accessed 1 July 2015).

38 Ibid.

39 Galeotti, "Invasion of Ukraine."

40 Mark Galeotti, “Ukraine's Mob War," Foreign Policy, 1 May 2014, http://foreignpolicy.com/2014/05/01/ukraines-mob-war/ (accessed 1 July 2015).

41 Galeotti, "Invasion of Ukraine." 
sacrificed their lives: a brighter future for Ukraine without corruption robbing society and future generations.

\section{Militias}

The maligned system of politics and armed groups in Ukraine is not a new phenomenon, but a product of the Russian mafia state following the fall of the Soviet Union. As the debate over Ukraine's integration into either Europe or Russia intensified, politicians and oligarchs aligned with armed groups or created their own private armies in order to protect their interests. ${ }^{42}$ Estimates put the number of the pro-Ukrainian volunteer militias at about 30 groups, the most prominent of which are the Azov Battalion, Dnipro Battalion and the Donbas Battalion. When war broke out in early 2014, these groups confronted pro-Russian separatists in the absence of Ukrainian armed forces. ${ }^{43}$

The Right Sector played a pivotal role in defending EuroMaidan activists against the pro-Yanukovych police force that attempted to break up the protestors, and has been credited with playing an important part in fighting in eastern Ukraine. The Right Sector has since gained political representation in the Ukrainian parliament, where it holds one seat. ${ }^{44}$ Despite the organization's support for EuroMaidan and its combat role, the Right Sector is still entrenched in "old ways" of doing business, such as extortion and smuggling, which undermine its political and nationalistic platform. ${ }^{45}$ Other militias that took part in overthrowing Yanukovych have been integrated into Ukraine's National Guard. $^{46}$

Perhaps the most revered militia unit from the start has been the Donbas Battalion, which was originally made up of fighters from Donbas who wanted to keep Ukraine unified. Now the unit consists of volunteers from all over Ukraine and other countries. At one point, Ukrainian-American Mark Paslawsky fought in the Donbas Battalion until he was killed in a botched operation in eastern Ukraine. Paslawsky, a West Point graduate, had served as an elite ranger in the US military. Before his death, he warned of a "Maidan 3.0,"

42 Amanda Taub, "Pro-Kiev Militias Are Fighting Putin, but Has Ukraine Created a Monster It Can't Control?" Vox, 20 February 2015, http://www.vox.com/2015/2/20/ 8072643/ukraine-volunteer-battalion-danger (accessed 1 July 2015).

43

44 "The Hand That Feeds: Kiev Now Unable to Survive without Extremist Support," Sputnik, 1 July 2015, http://sputniknews.com/europe/20150701/1024081705.html (accessed 1 July 2015).

45 John E. Herbst, "Here's How to Make Sense of the Violence in Western Ukraine: Follow the Money," Atlantic Council, 14 July 2015.

46 Laetitia Peron, "US Army Walks Cultural Minefield Training Ukraine Troops," Yahoo News, 24 April 2015, http://news.yahoo.com/us-army-walks-cultural-minefieldtraining-ukraine-troops-151608593.html (accessed 1 July 2015). 
whereby after the war, militias that worked together would grow tired of the lack of reforms in Kyiv and continued systemic corruption. ${ }^{47}$

Donbas Battalion Commander Semen Semenchenko said, "We aren't anybody's army, and we don't have a single sponsor. We have many sponsors, including just ordinary people who give us as little as food and water supplies," and although last year the battalion has operated under the control of the Ministry of Internal Affairs, it still maintains some autonomy to conduct training and equipping using its own funds. ${ }^{48}$ Semenchenko visited Washington in September 2014 to lobby on behalf of his men to receive greater US support. He will also be running for parliament in the upcoming elections, and has said "I want to make Ukraine into another Israel. I mean, a country that has seen the type of danger [Israel] has [sic] must drastically change its approach to national security and create a modern military with Special Forces to protect itself." 49

Kyiv officials walk a thin line of outwardly condemning illegal armed groups in Ukraine and passively supporting pro-Ukrainian militias that wield significant power and fighting forces. The Ukrainian government continues to work to unify these groups under either the Ministry of Defense or Interior, despite recent confrontations and lack of desire to integrate. ${ }^{50}$ In April 2015, the Right Sector's leader, Dmytro Yarosh, was appointed as an advisor to the Ministry of Defense in a move to consolidate the group within the ministry by giving it a seat at the table. Ultimately, officials hope that integrating all militias under the command and control of the government will achieve unity of effort against a common enemy - Russia. ${ }^{51}$ These groups are credited with seeing EuroMaidan through to the end and defending Ukraine in the face of Russian aggression; however, as the war goes on they represent a glaring threat to the central government. $^{52}$

47 Simon Ostrovsky, "The Only American Fighting for Ukraine Dies in Battle," Vice News, 20 August 2014, https://news.vice.com/article/the-only-american-fighting-forukraine-dies-in-battle (accessed 1 July 2015).

48 Sabra Ayres, "The Donbass Battalion prepares to save Ukraine from separatists," $A$ I Jazeera America, 29 June 2014, http://america.aljazeera.com/articles/2014/6/28/ the-donbas-battalionpreparestosaveukrainefromseparatists.html (accessed 1 July 2015).

49 Mark Snowiss, "Q\&A: Ukraine's Donbas Battalion Commander Seeks US Support," Voice of America, 16 September 2014, http://www.voanews.com/content/ukrainedonbas-battalion-commander-seeks-us-support/2452051.html (accessed 1 July 2015).

50 "Ukrainian Militias Are above the Law According to Kiev," Global Research, 3 May 2015, http://www.globalresearch.ca/ukrainian-militias-are-above-the-law-accordingto-kiev/5447023 (accessed 1 July 2015).

51 Claire Rosemberg, "Ukraine far-right leader made army advisor in move to control militias," Business Insider, 6 April 2015, http://www.businessinsider.com/afpukraine-far-right-leader-made-army-advisor-in-move-to-control-militias-2015-4 (accessed 1 July 2015).

52 Taub, "Pro-Kiev militias." 
Pro-Russian separatist militias are known opportunists from backgrounds as organized criminals, mercenaries, Cossacks or Chechens. ${ }^{53}$ They have been operating since the annexation of Crimea, seizing government buildings and throwing out local government administrators and law enforcement. ${ }^{54}$ Recruitment is not only limited to eastern Ukraine, as recruitment centers have been established throughout Russia. Separatists as well as pro-Ukraine militias use Facebook or VKontakte for recruitment and organization. ${ }^{55}$ Putin may not have direct control over these groups, and if he did want to abruptly end the war, it may have become impossible to put the lid back on the chaotic situation. Russia could be faced with the same problem as Ukraine, namely of returning fighters being dissatisfied with the conduct of the war by the Kremlin and wanting to take action in their own hands. Many right-wing groups are angry with Putin for not fulfilling the Novorossiya project and providing greater support for the war effort. ${ }^{56}$

There is concern that the worst is yet to come in eastern Ukraine. As more men receive military training and the region becomes flooded with weapons, it could lead to greater violence. As of now militias are aligned with Moscow or Kyiv, but when a political resolution is reached or one side comes out victorious, the militias will need to decide to disband or fight for personal interests. Militias on both sides are conducting their own operations and fighting and winning against government forces, showing that they will be a force to be reckoned with in the future. ${ }^{57}$

The most dangerous scenario is the proliferation of highly destructive weapons to disjointed militias lacking tight command and control. The shooting down of flight $\mathrm{MH} 17$ with a Russian-designed SA-11 antiaircraft missile demonstrates the reality of non-state actors acquiring highly sophisticated weapons systems, thus posing a direct threat to the international community.

53 Paul Stronski, "Broken Ukraine," Foreign Affairs, 18 March 2015, also available at http://carnegie-mec.org/2015/03/18/broken-ukraine (accessed 1 July 2015).

54 Alison Smale and Andrew Roth, "Ukraine Says That Militants Won the East," The New York Times, 30 April 2014, http://www.nytimes.com/2014/05/01/world/europe/ ukraine.html (accessed 1 July 2015).

55 Sarah Kaufman and Vladi Vovcuk, "Are the Russians Losing Interest in Ukraine?" The Week, 13 June 2015, http://theweek.com/articles/560117/are-russians-losinginterest-ukraine (accessed 1 July 2015).

56 Stronski, "Broken Ukraine."

57 Stephen Biddle and Ivan Oelrich, "Why the Ukraine Separatists Screwed Up: Badly Organized Insurgents Can't Master Complex Weapons Systems," The Washington Post, 21 July 2014, www.washingtonpost.com/blogs/monkey-cage/wp/2014/07/ 21/why-the-ukraine-separatists-screwed-up-badly-organized-insurgents-cantmaster-complex-weapons-systems/ (accessed 18 July 2015). 


\section{NGOs and GONGOs}

Throughout the 2000s, Putin observed the power of Western democratic NGOs throughout the former Soviet Union and has now begun countering their democratization objectives with Russian NGOs. Russia's objectives are to promote the "Russian" model, seek to reduce influence of the US and once again become the center of gravity for the region. When Putin returned to power he set about nationalizing Russian civil society, namely pro-Russian think tanks, human rights groups, election observers, youth groups, Eurasianist integration groups and Cossack networks. All of these organizations have been heavily involved in weakening Ukraine: some were used to counter the Revolution of Dignity, support the annexation of Crimea and to undermine sovereignty and stir social tensions throughout Ukraine. ${ }^{58}$

Beyond the borders of the former Soviet Union, Russia supports about 150 GONGOs with the goal of influencing policymakers, political elite and youth. Compared to Western lobbyist organizations that rely on the strength of their argument, Russians see money as the most influential tool of persuasion. The development of business links in Germany, Italy and France has been influential in Europe's lackluster response to Russia's actions in Ukraine. Moreover, Europe and the US have taken military intervention off the table, which has greatly undermined the negotiating strength of the international community. ${ }^{59}$ These operations have had a direct impact on the war in Ukraine by creating opposition in the West to Russian sanctions, military intervention and the international community's ability to speak with one voice to condemn Russian aggression.

During the annexation of Crimea, the Cooperation Agency, the Luzhkov Sevastopol Foundation and the Moscow House of Crimea funded the separatist leadership. Sergey Tsekov, a Crimean Russian separatist leader, has run the youth movement in Crimea since 2008. Through his organization he promoted Russian values and interests by organizing demonstrations against NATO, proRussian performances and promoting reunification with Russia. The Novorossiya project was also strongly supported by Russian GONGOs with religious undertones. The Izborskiy Club, for instance, was instrumental in organizing a new government in eastern Ukraine and the St. Basil's Foundation cooperates with the new "Donetsk People's Republic" (DNR) by providing aid to the war-torn region. Several recruitment organizations such as Russian Volunteers, the Russian Imperial Movement and Veterans and Cossacks have fed the meat grinder in Ukraine with fresh ideological Russians. ${ }^{60}$

In the past, Western NGOs enjoyed the advantage of an open society and massive funding in the former Soviet space. To counter the influence of these NGOs, Russia has used GONGOs to promote Russian values. GONGOs have lost

\footnotetext{
58 Lough, et al., Russian Influence Abroad.

59 lbid.

60 Ibid.
} 
their appeal as international opinion of Russia is increasingly negative as the conflict in eastern Ukraine drags on into its second year. Their narrative of a Eurasian community with Russia as the center of gravity is becoming less appealing to their target audiences throughout the former Soviet space, and especially in Ukraine. ${ }^{61}$

Ukrainian civil society has been the most active within the former Soviet space. The National Endowment for Democracy (NED) has been instrumental in providing funding, and currently sponsors more than 80 NGOs in Ukraine that work in areas such as supporting civil society's participation in government, strengthening public sector transparency and media development. For example, the Independent Association of Broadcasters works with youth to develop bipartisan video segments comparing various political parties' platforms. ${ }^{62}$ NED's support for strengthening NGOs and societal inclusion may have contributed to Ukrainians deposing former president Yanukovych following mass protest in Kyiv. The appeal of an open and inclusive society more integrated with the greater European neighborhood proved superior to continued subservience to Russia.

Also present in Ukraine, humanitarian NGOs inject themselves into events by reporting on prisoner of war abuses and war crimes as well as working with internally displaced persons. Amnesty International released a report in May called Breaking bodies: Torture and Summary Killings in Eastern Ukraine on prisoner abuse after interviewing 33 former prisoners, half from the Ukrainian side and half from the separatist/Russian side. According to their account, prisoners were "beaten until their bones broke, tortured with electric shocks, kicked, stabbed, and hung from the ceiling, deprived of sleep for days, threatened with death, denied medical care, and subjected to mock executions." 63

Pro-Russian and pro-Western civil NGOs and GONGOs are actively pursuing conflicting goals in Ukraine. Over time, the natural desires of Ukrainian civil society to shed corruption and reject the model of the Russian mafia state have exploded in uprisings of society against elite politicians whose loyalty to Moscow supersede the will of Ukrainians.

\section{Diasporas}

Since 1940, the interests of the 961,100 Ukrainians in the US have been represented by the Ukrainian Congress Committee of America, Inc. (UCCA). ${ }^{64}$ Its pub-

61 Ibid.

62 National Endowment for Democracy, www.ned.org/where-we-work/eurasia/ukraine (accessed 19 July 2015).

63 Amnesty International, Breaking Bodies: Torture and Summary Killings in Eastern Ukraine (London: Amnesty International, 2015), http://www.amnestyusa.org/sites/ default/files/ukraine_briefing_final.pdf (accessed 30 June 2015).

64 Olena Lennon, "Ukrainian Politics Abroad," Foreign Affairs, 17 March 2015, www.foreignaffairs.com/articles/eastern-europe-caucasus/2015-03-17/ukrainianpolitics-abroad (accessed 30 June 2015). 
lic relations office, the Ukrainian National Information Service (UNIS), located in Washington, is very active. Since the Revolution of Dignity began in late 2013, the UCCA and UNIS have been working to raise the issues of Russian aggression, preserving Ukraine's territorial integrity and greater US support for Ukraine during the ongoing war. The UNIS organizes advocacy days in Washington and works closely with the newly-formed Senate Ukraine Caucus to discuss policy measures that will strengthen the strategic relationship between the US and Ukraine, especially to deter further Russian aggression. UCCA's reputation and credibility has strengthened government and business contacts during the difficult period of war and necessary reforms have thus been enacted by the government. ${ }^{65}$

Representatives from Ukraine have also made a continuous effort to engage the Ukrainian diaspora in the US. Early this year Ivan Rodichenko, a volunteer fighter, visited a New York Ukraine Chapter and brought US-Ukrainians a personal story and pictures from the front lines. During Rodichenko's presentation, the audience donated funds to purchase equipment and supplies for his unit. "Without this help from people like them, the war is already lost," said Rodichenko. He represents one of 32 defense battalions, each with its own spokesman who travels to various diaspora groups to raise awareness of the poorlyequipped volunteer units that receive minimal funding from Kyiv. The Ukrainian diaspora throughout the world has donated "hundreds of thousands of dollars" to Rodichenko's unit, which went to purchase basic military personnel equipment such as sleeping bags, clothing and radios. ${ }^{66}$

In Portugal, a country of 10 million people, the Ukrainian diaspora represents the second largest immigrant community, with 45,000 Ukrainians. According to the Ukrainian World Congress, almost one-third of Ukrainians live outside Ukraine. Thus, diaspora support is vital in the face of Russian aggression and will be instrumental in rebuilding the country and paying of its foreign debt in the future. For Ukraine-one of Europe's poorest countries-remittances make up 5 percent of GDP. During the Revolution of Dignity in EuroMaidan, Ukrainians in Portugal raised $\$ 55,000$ for the demonstrators. ${ }^{67}$ Canada also has a large and active Ukrainian diaspora, which over the past year has raised between $\$ 10-15$ million. ${ }^{68}$

65 www.ucca.org/index.php?option=com_content\&view=article\&id=13\&Itemid=10\& lang=en.

${ }^{66}$ Christopher Harress, "How the Ukrainian Diaspora in the US Is Funding the War Effort in East Ukraine," International Business Times, 15 March 2015, http://www.ibtimes.com/how-ukrainian-diaspora-us-funding-war-effort-eastukraine-1846674 (accessed 30 June 2015).

67 Paul Ames, "Ukraine's Diaspora Could Be Key to Recovery," Global Post, 22 May 2014, www.globalpost.com/dispatch/news/regions/europe/140301/ukrainiandiaspora-ukraine-economic-recovery (accessed 30 June2015).

68 Ibid. 
The Ukrainian diaspora has mobilized itself financially, technically and personally, fighting on the front lines to come to the aid of its countrymen. Grassroots efforts supply both the volunteer units and government forces with over half of what they need, making the diaspora a powerful actor. This is a more efficient and transparent process compared to an improving, yet still corrupt, poorly funded and dysfunctional defense system. ${ }^{69}$

Furthermore, diasporas do have an effect on political leaders, especially in Canada, where Steven Harper was ranked within the top 10 "most influential promoters of Ukrainian issues in the world." ${ }^{70}$ The Ukrainian diaspora has also proven to be a powerful force in supporting Ukraine's move toward greater independence and democratization. From humanitarian aid to wounded soldiers receiving the highest level of care in other countries, the Ukrainian diaspora is providing funding where the government in Kyiv cannot. ${ }^{71}$ Outside of the UCCA, the Razom for Ukraine group unites highly skilled professionals in the Ukrainian diaspora inside and outside the US, and has raised around $\$ 135,000$ for the Maidan protests. $^{72}$

\section{Conclusion}

The current situation in Ukraine has highlighted the fact that in this new age of warfare, non-state actors play a larger role than ever before. They greatly impacted the root causes leading up to the Revolution of Dignity, the annexation of Crimea and the prolonged war in eastern Ukraine. Russia has found it necessary to employ a myriad of traditional non-state tools to protect its strategic interests in Ukraine. In Kyiv, the Ukrainian government is dealing with an economic crisis and fighting a war for its very survival, but must also take into consideration interests of non-state actors. Leaders who understand the influence of these groups, sources of funding and motivation will be more able to navigate this complex environment, where one misinformed decision could lead to negative consequences and prolonged suffering. The twenty-first century battlefield in Ukraine is complex and characterized by the active participation of non-state actors, creating a hotbed for hate and deadly struggle over geostrategic, economic and security interests. The conclusion of the war will hinge upon the ability of either side to capitalize on the influence non-state actors wield not only in Ukraine, but transnationally.

69 Ibid.

70 Mark Mackinnon, “Bypassing Official Channels, Canada's Ukrainian Diaspora Finances and Fights a War against Russia," The Globe and Mail, 26 February 2015, http://www.theglobeandmail.com/news/world/ukraine-canadas-unofficial-

71 Lennon, "Ukrainian Politics Abroad." war/article23208129/ (accessed 30 June 2015).

72 Katya Soldak, "In a Time of Crisis, Ukrainians Abroad Unite," Forbes, 10 April 2014, www.forbes.com/sites/katyasoldak/2014/04/10/in-a-time-of-crisis-ukrainiansabroad-unite/ (accessed 30 June 2015). 


\section{About the author}

MAJ Joshua Mulford is from Centreville, Virginia. In 2004 he graduated from Virginia Military Institute and commissioned as a Second Lieutenant in the U.S. Army Infantry. Joshua deployed twice to Iraq and has served throughout the former Soviet Union. Joshua has completed his Masters in International Policy and Practice with a Concentration in Eurasian Affairs from George Washington University, Washington D.C. He is currently attending the Joint Military Attaché School and is the Deputy Attaché (designate) to the U.S. Embassy Yerevan. MAJ Mulford is married to Sohira; they have two daughters, Anais and Laurel.

E-mail: jpmulford@gwmail.gwu.edu 